\title{
Integration and Transformation: A Study of the Sun and the Moon Depicted in the Imagery of Fuxi and Nüwa
}

\author{
Jinchao ZHAO*
}

\begin{abstract}
The present research focuses on the depiction of the sun and moon in the imagery of Fuxi and Nüwa during the Han and Wei-Jin periods. Through typological and iconographical approaches, it proposes four primary modes in terms of the ways in which the sun and the moon are combined with Fuxi and Nüwa. It contributes to the current field by providing new perspectives for readdressing some issues that remain underexplored. First, it challenges the over-absolute identification of the earliest representation of Fuxi and Nüwa in a pair, and that of Changyi and Xihe, another set of paired deities recorded to be in close relation to the celestial world, in Western Han mural tombs from the Luoyang area, and instead suggests a shift of focus to the recognisable distinctions in visual details, such as the chronological sequence of the application of the first and second modes in the Luoyang Han tomb paintings, and the masculine appearances of both the deities depicted in the Western Han Qianjingtou tomb. Further examinations of the development and dissemination of each mode through the Han and Wei-Jin eras reveals complicated interactions between different regions and exchanges of motif with other forms of imagery. The local tradition of depicting Fuxi and Nüwa, together with that of the depiction of the sun and moon in Nanyang, has been incorporated into the formation of the sun and moon in anthropomorphic representations in the Southwest. Finally, this research proposes that it is more significant to organise the surviving materials through the development and context of each visual element represented in the scene, rather than making an absolute identification based on scattered evidence.
\end{abstract}

Keywords: Fuxi, Nüwa, the sun and moon, mural tombs, stone sarcophagus

\section{Integracija in transformacija: študija motivov sonca in lune pri upodobitvi Fuxija in Nüwe}

\section{Izvleček}

Pričujoča razprava se osredotoča na motiv sonca in lune pri upodobitvi Fuxija in Nüwe v času dinastij Han in Wei Jin. Na osnovi tipološkega in ikonografskega pristopa predlaga štiri osnovne modele upodobitve sonca in lune v odnosu do Fuxija in Nüwe, s čimer izpostavi

Jinchao ZHAO, $\mathrm{PhD}$ candidate in Art and Architectural History, 
nove vidike za ponovno prevrednotenje nekaterih nenaslovljenih vprašanj. Najprej postavlja pod vprašaj absolutno identifikacijo najzgodnejše upodobitve Fuxija in Nüwe ter Changyi in Xihe, še enega para božanstev, povezanih z nebeškim svetom, ki jih najdemo v grobnicah s poslikavo v mestu Luoyang iz časa dinastije Zahodni Han. Pri tem predlaga preusmeritev pozornosti na prepoznavne razlike $\mathrm{v}$ vizualnih podrobnostih, kot jih lahko zaznamo v kronološkem zaporedju uporabe prvega in drugega modela $\mathrm{v}$ grobnicah iz mesta Luoyang ter v bolj možatem videzu obeh božanstev v grobnici Qiangjingtou iz časa Zahodnega Hana. Nadaljnje proučevanje razvoja in širitve posameznih modelov v dinastijah Han in Wei Jin prikaže kompleksne povezave med različnimi regijami ter izmenjave motiva $\mathrm{z}$ ostalimi podobami. Lokalna tradicija upodobitve Fuxija in Nüwe skupaj s prikazom sonca in lune iz kraja Nanyang je bila na primer vključena v oblikovanje podobe sonca in lune kot antropomorfične reprezentacije, ki je postala opazna zlasti v jugozahodnem delu kitajskega območja. Pričujoči prispevek v zaključku tudi poudari pomembnost obravnave ohranjene materialne dediščine prek razvoja ter vključitve posameznih vizualnih elementov v celotne prizore in ne zgolj formiranja absolutne identifikacije na podlagi posameznih dokazov.

Ključne besede: Fuxi, Nüwa, sonce in luna, grobnice s poslikavo, kamniti sarkofagi

\section{Introduction}

Fuxi 伏羲 and Nüwa 女媧 were among the most prominent deities in Chinese genesis mythology. Fuxi is best known as an ancestor of human beings, and Nüwa is the goddess who created human beings by moulding yellow earth together and patching the broken sky. In visual culture, Fuxi and Nüwa usually appear as a couple with human faces and snake-like bodies that are sometimes intertwined with each other. The couple was frequently depicted on chamber walls of ancestral shrines (Fig. 1), stone sarcophagi (Fig. 2), and the domed ceiling of tombs (Fig. 3) during the Han Dynasty.

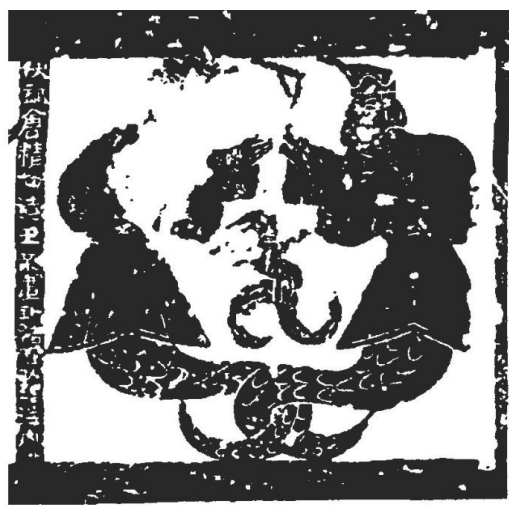

Figure 1: Fuxi and Nüwa at the Wu Liang Shrine, Shandong. Second century CE. Eastern Han (After Jiang 2000, fig. 49). 


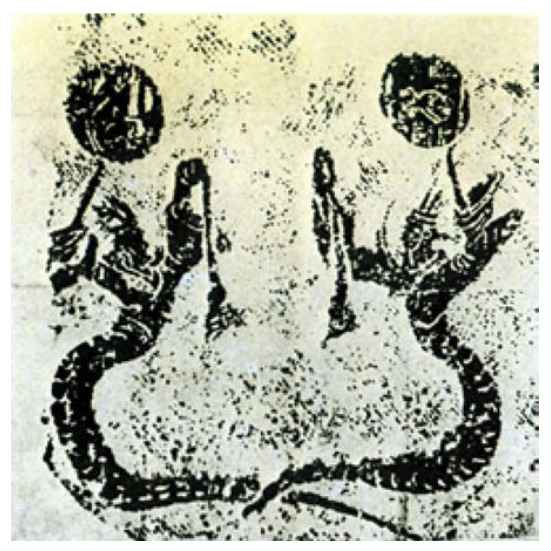

Figure 2: Fuxi and Nüwa on the stone sarcophagus found at Baozishan, Xinjin, Sichuan. Ink rubbing. Second century CE. Eastern Han (After Gao 1998, fig. 202).

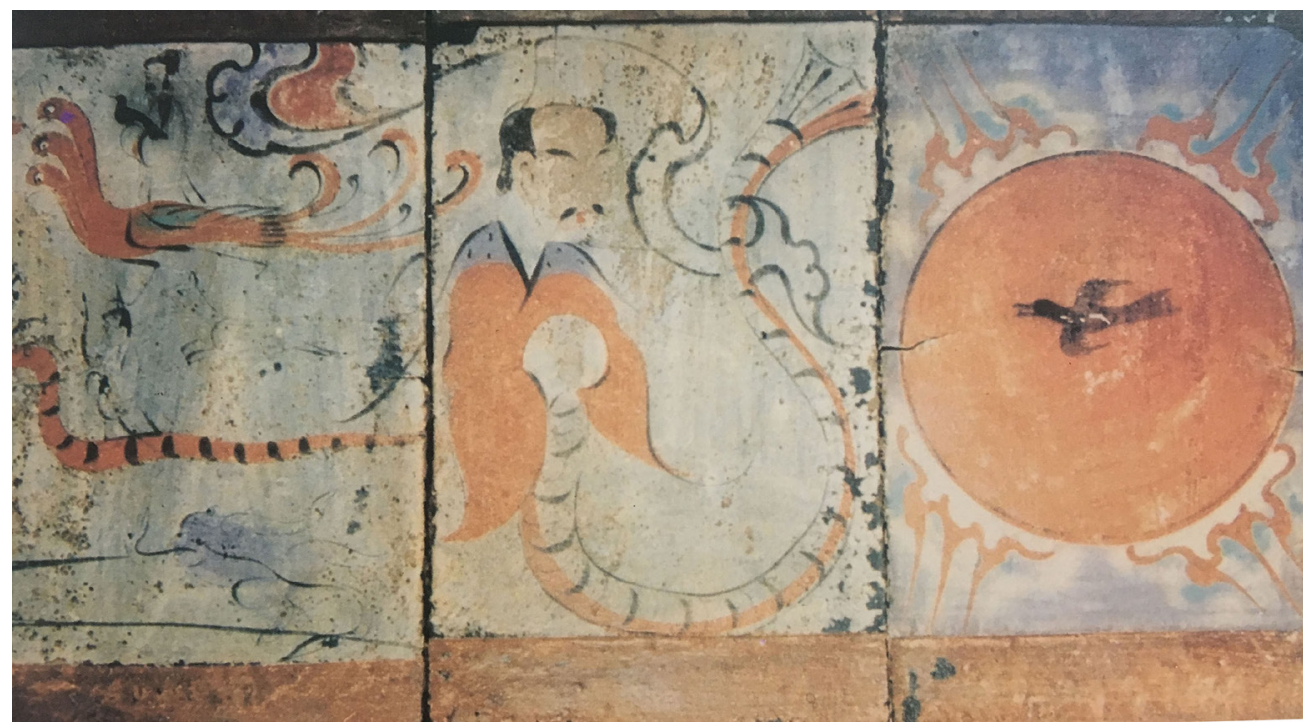

Figure 3: Fuxi and the sun on the ceiling of the tomb of Bu Qianqiu, Luoyang, Henan. 86 BCE-49 BCE. Western Han (After Huang 1996, 73).

When it comes to the Wei-Jin 魏至 tombs dated from the third to fourth centuries $\mathrm{CE}$, the couple frequently appears on the covers of wooden coffins (Fig. 4), or pictorial bricks on tomb walls (Fig. 5). In the Tang Dynasty from the seventh to the ninth centuries, most of the depictions of the couple have been discovered at Turfan 吐魯番 in the Hexi Corridor 河西走廊, in the form of silk paintings that 
cover wooden coffins (Fig. 6) (Deng 2010; Chen 2011). The union of Fuxi and Nüwa is considered like a diagram of yin 陰 and yang 陽, the two universal forces in the cosmology of the time, according to their different genders and the usually intertwined bodies of the couple (Birrell 1993; Lewis 1999, 204; Wu 2012). In addition, the depiction of the sun and moon is generally considered a coherent visual component of the Fuxi and Nüwa imagery, appearing in the shape of round discs that contain a toad in the moon and a three-legged crow in the sun, respectively, since the Han Dynasty (Fig. 2, 3), while an abstract depiction of the sun with radiating beams inside and the moon in the crescent shape became dominant in Tang burial arts of the Hexi Corridor (Fig. 6).

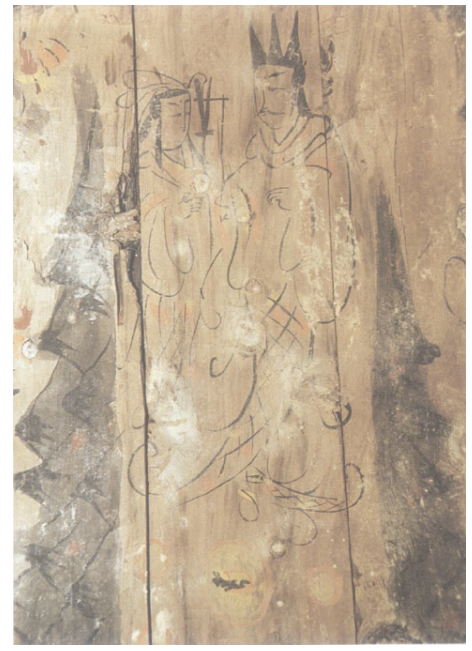

Figure 4: Fuxi and Nüwa depicted on coffin cover from Maozhuangzi, Jiayuguan, Gansu. Third century CE. Wei-Jin period (After Kong 2006, fig. 14).

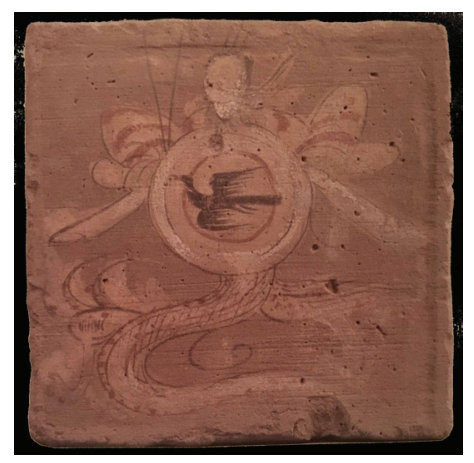

Figure 5: Pictorial Brick from the Dunbuang Museum. Dunbuang, Gansu. Third century CE. Wei-Jin period (After Dunhuang Municipal Museum 2017, 12). 


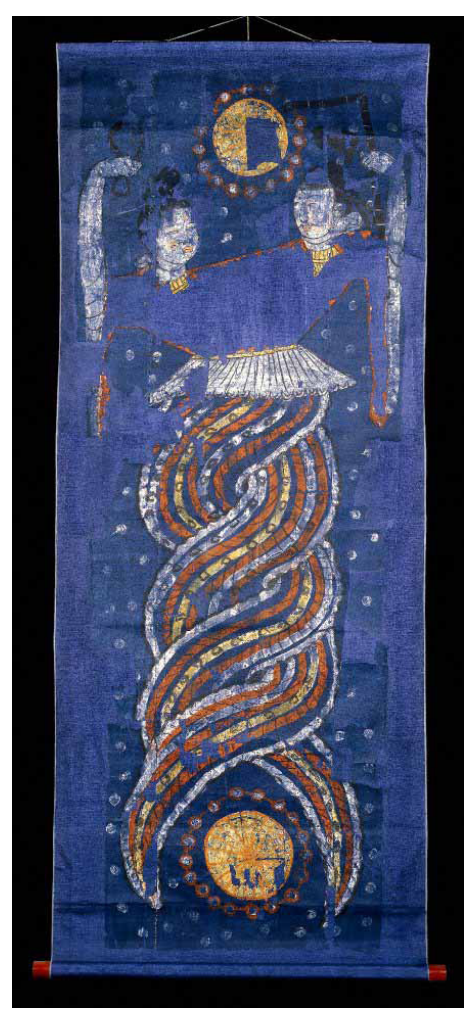

Figure 6: Fuxi and Nüwa from Astana, Turfan. Seventh to ninth century CE. Tang dynasty (After The British Museum, Museum no. 1928-1022-0.203).

However, the sun and moon are not always the standard attributes of Fuxi and Nüwa in the Han Dynasty, and sometimes are instead the compass and square (Fig. 1), which are spread across the country, or the auspicious plant lingzhi 靈芝 (Fig. 7), particularly popular in the region of present-day Shandong and Nanyang 南陽 (in today's Southern Henan). How were the pair of the sun and moon integrated into the imagery of Fuxi and Nüwa? What was the specific significance of the sun and moon to Fuxi and Nüwa? And how to perceive the sun and moon in the larger iconographic scheme of the Fuxi and Nüwa? Moreover, how does the combination of the two pairs function in the ritual and burial contexts? These questions remain insufficiently examined in current scholarship. ${ }^{1}$

1 Discussion of the connection between the two pair in major scholarships is very brief. There are monographic discussions on the depiction of the sun and the moon as celestial symbols and the two deities as a pair that possesses the power of fertility, but without any focused and thematic study of their connections. 

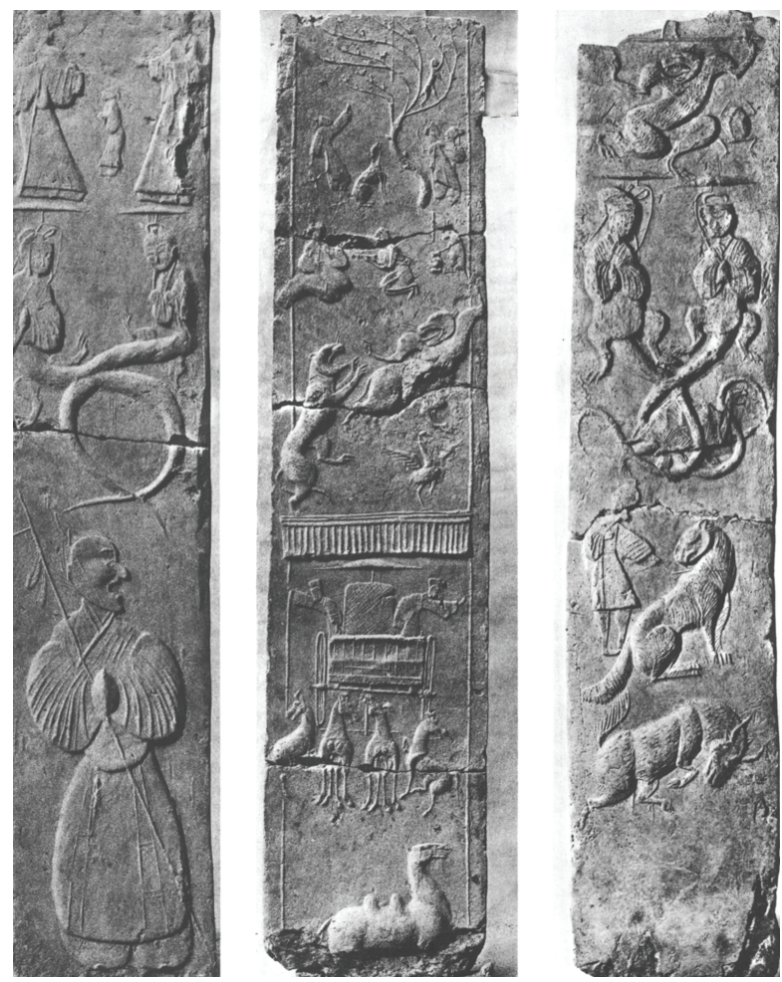

Figure 7: Eastern Han tomb from Xinye Libu, Nanyang. Second century CE. Eastern Han (After Jiang 2001, fig. 58).

Through a thorough examination of the representations of Fuxi and Nüwa and that of the sun and moon from the Han to the Wei-Jin periods, the present essay proposes four primary modes in terms of the ways in which the two pairs are combined. Each mode shows a particular development of the imagery that includes both the pairs in specific historical and regional contexts. In the first mode, the sun and moon appear besides Fuxi and Nüwa (Fig. 3). It is an "archaic" mode that was only found on ceilings of Western Han tombs from the then political and economic centre of the city of Luoyang (in today's northern Henan), and was not inherited by later traditions. The second mode refers to the arrangement of the sun and moon held in hands by Fuxi and Nüwa respectively. It could be termed "standard," as it is the most popular mode that has flourished through the long historical course of depicting Fuxi and Nüwa in a pair. In comparison to other modes, it is predominant in Nanyang (Fig. 8) and the Southwest (in today's Sichuan and Chongqing) (Fig. 2) during the Eastern Han, as well as the Hexi Corridor in the Wei-Jin era (Fig. 5). 


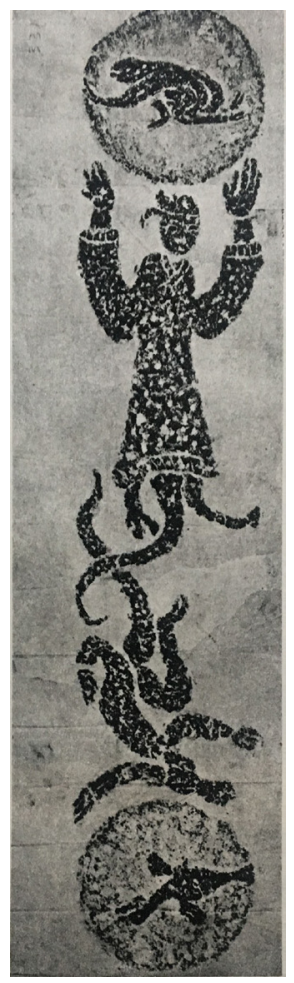

Figure 8: Fuxi and Nüwa from Tanghe Huyang, Nanyang, Henan. First century CE. Eastern Han (After Nanyang shi bowuguan 1981, fg.158).

The third mode depicts the sun and moon as embraced in front of the chest of Fuxi and Nüwa. It was applied occasionally during the Han Dynasty in Shandong/Jiangsu (Fig. 9), Nanyang (Fig. 10), and Shaanxi (Fig. 11), but not in the Southwest. During the Wei-Jin period, it became the predominant mode that was depicted on the surface of wooden coffins (Fig. 12) or pictorial bricks used in burials of the Hexi Corridor. Last, the fourth mode depicts the sun above Fuxi and Nüwa while the moon below (Fig. 6), naturally in a vertical setting. Although it was applied primarily to silk paintings found in burials dated to the Tang from the seventh to ninth centuries, later than the time range of the current research, I include it since its prototype already appeared in the Wei-Jin era. 

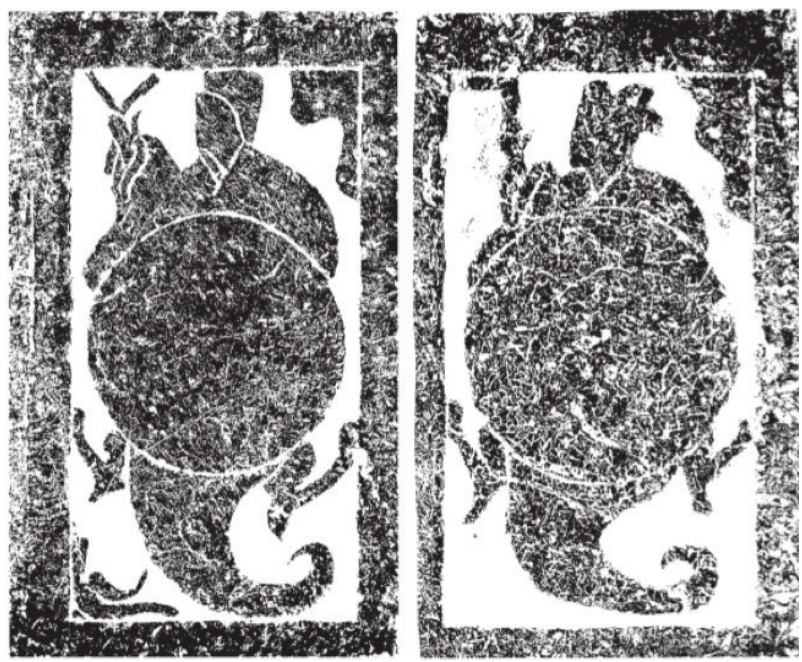

Figure 9: Fuxi and Nüwa from Feixian, Shandong. Second century CE. Eastern Han (After Gao 2001, figs. 89 and 90).
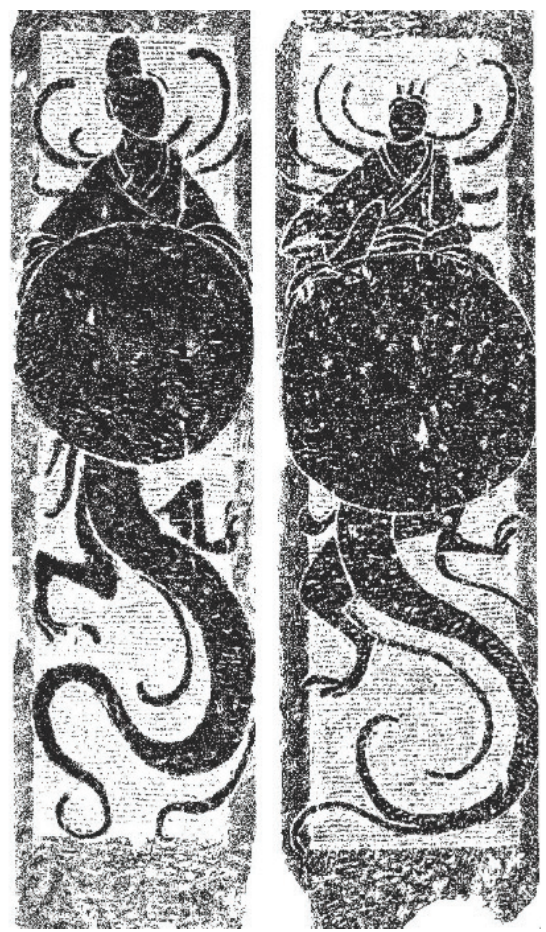

Figure 10: Fuxi and Nüwa from the Pictorial Stone Tomb at Qilin'gang, Nanyang, Henan. Second century CE, Eastern Han (After Huang et al. 2008, fg.154). 


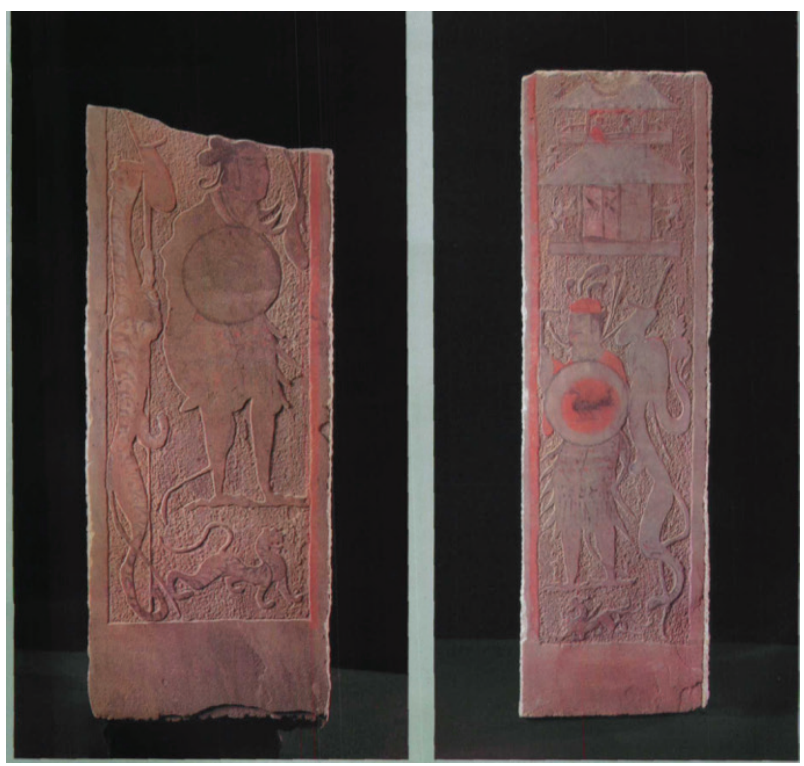

Figure 11: Fuxi and Nüwa embracing the sun and the moon. Han tomb at Dabaodang, Shenmu, Shaanxi. Eastern Han (After Shaanxi sheng kaogu yanjiusuo 1997, figs. 1 and 2).
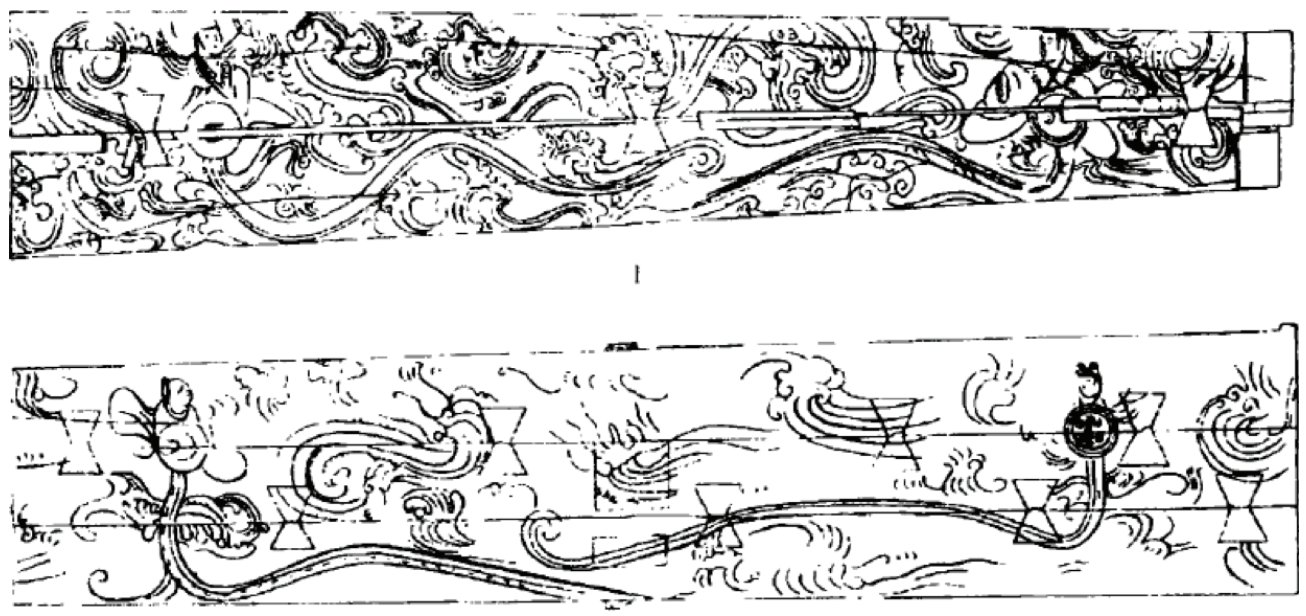

Figure 12: Fuxi and Nüwa on the coffin cover of the M1 Tomb from Jiayuguan, Gansu. Third century CE. Wei-Jin period (After Zhao 2005, fig. 1).

Further iconographic analysis of the four modes within their contexts sheds light on revising issues remaining unclear in the identification of Fuxi and Nüwa. The two deities depicted in the first and second modes in Luoyang area 
appear to be more closely related to the legend of Changyi 常儀 and Xihe 羲 和, who were recorded as attendants of the sun and moon, instead of Fuxi and Nüwa. It discloses that the third mode, which has the sun and moon embraced by Fuxi and Nüwa, has exerted influence on the imagery of the sun god 日神 and moon goddess 月神, the anthropomorphic forms of the sun and the moon, in the Southwest region (Fig. 13).

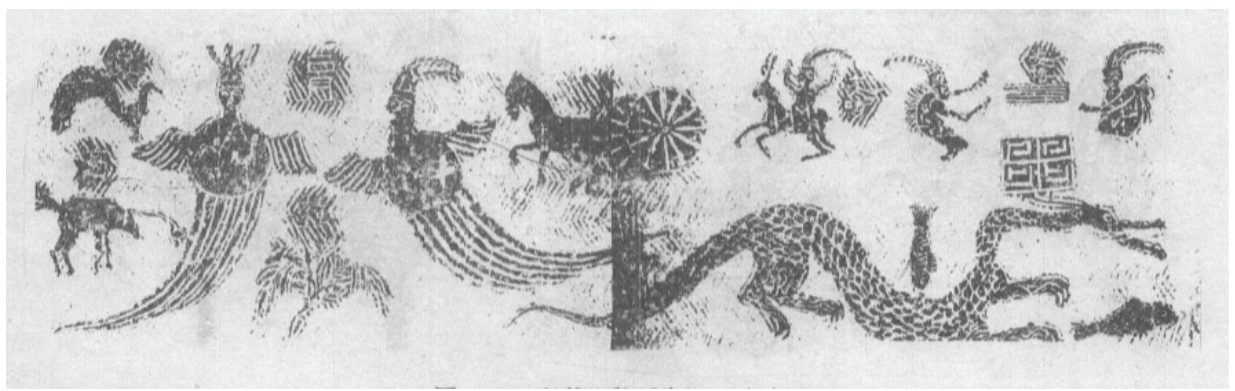

Figure 13: The sun and moon on the no. 3 stone sarcophagus from Guitoushan, Jianyang, Sichuan. Second century CE, Eastern Han (After Neijiang shi wenguansuo 1991, fig. 11).

\section{The Sun and Moon in Literary Traditions}

The sun and moon usually appear together as cosmic symbols. They can be further interpreted respectively as representations of the essence of yang and yin that lay the foundation for the cosmogonic process of the creation of the universe. ${ }^{2}$ The literary description of the sun's relation to yang and the moon's relation to yin becomes the primary evidence for scholars' interpretation of the integration of the sun and moon into the imagery of Fuxi and Nüwa. Fuxi and Nüwa have been associated with yang and yin in many sources. In Huainanzi 淮南子, it is the union of Fuxi and Nüwa that caused the process of the separation of Heaven and Earth, and thus the separation of yang and yin. The two deities were also recorded as the gods of the sun and moon, respectively (He 1998, 503-4).

Usually inside the moon is a hare or toad, and inside the sun a bird, or a more detailed three-legged crow. In Ling xian 靈憲 (Spiritual Constitution), it records that:

日者, 陽精之宗, 積而成鳥, 象鳥而有三趾...月者陰精之宗, 積 而成獸, 象蜍兔。

The sun is the fundamental essence of yang. It accumulates into a bird

2 In the third century text Huainanzi, it is recorded that 日者, 陽之主也...月者, 陰之宗也 (The sun is the master of yang... The moon is the foundation of yin...) (He 1998,171-72). 
that looks like a crow with three legs...The moon is the fundamental essence of yin. It accumulates into an animal that looks like a toad or a hare (Liu 1965, 3216).

In some sources, the three-legged crow is recorded as an attendant of Xiwangmu 西王母 (The Queen Mother of the West), without any association with the moon. ${ }^{3}$ However, in the visual culture since the Western Han, the depiction of a three-legged crow in the sun usually appears in a pair with the moon.

\section{In Between the First and Second Modes: Fuxi and Nüwa, or Changyi and Xihe}

Examples that have been traditionally identified as the earliest representations of Fuxi and Nüwa are mural paintings from Han tombs near Luoyang in present-day Henan Province. ${ }^{4}$ This group of murals share some essential characteristics, especially their locations on the central strip of the ceiling or the upper part of the walls in the burial chamber. Fuxi and Nüwa are identified according to their human faces and snake-like bodies, and the incorporation of the sun and moon, which is rendered in the first or second modes of representing the sun and moon as classified in this research. If we examine the chronology of these tombs, it is interesting to notice that mural paintings that applied the first mode are dated to the Western Han period, around the first century BCE, while those applying the second are from the later period (Huang 1996; Yang 2003; He 2001). For instance, the earliest burials, such as Bu Qianqiu 卜千秋 tomb (Fig. 3) and the Qianjingtou 淺井頭 tomb (Fig. 14, 15), applied the first mode, which depicts the sun and moon besides Fuxi and Nüwa, while tombs of the Xin-Mang (Fig. 16) and Eastern Han (Fig. 17, 18) in general adopt the second mode, which has the sun and the moon upheld respectively by Fuxi and Nüwa. It seems quite clear that the first mode was once preferred but later replaced by the second mode in the Luoyang area.

3 In Shiji, "Sima Xiangru liezhuan" 史記 - 司馬相如列傳, ...吾乃今日睹西王母...有三足乌为之 使 (...I today saw the Queen Mother of the West...a three-legged crow is at her service...) (Sima 1959, 3060).

4 Around 15 Han tombs with murals have been discovered near Luoyang, the economic, political and cultural center during the Han Dynasty (Luoyang bowuguan 1977; Zhongguo shehui kexueyuan kaogu yanjiusuo and Henan dier gongzuodui 1985; Luoyangshi dier wenwu gongzuodui 1993; Huang 1996; He 2011; Vampelj Suhadolnik 2011). 


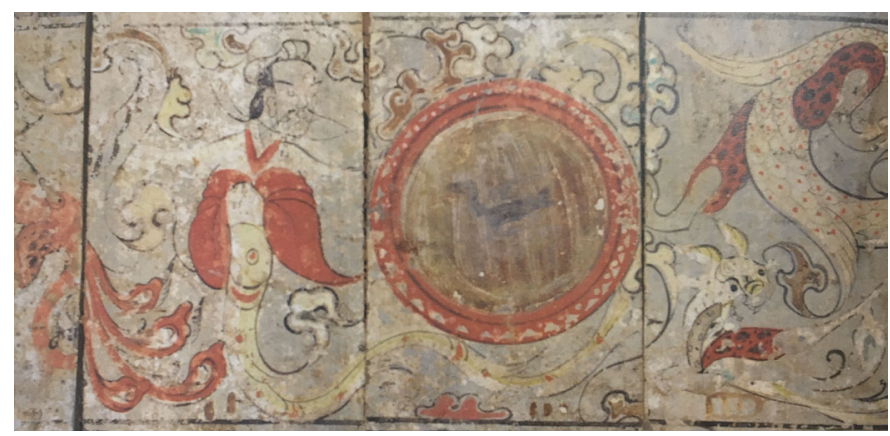

Figure 14: Fuxi and the sun on the ceiling of the Qianjingou tomb, Luoyang, Henan. First century BCE. Western Han (After Huang 1996, 82).

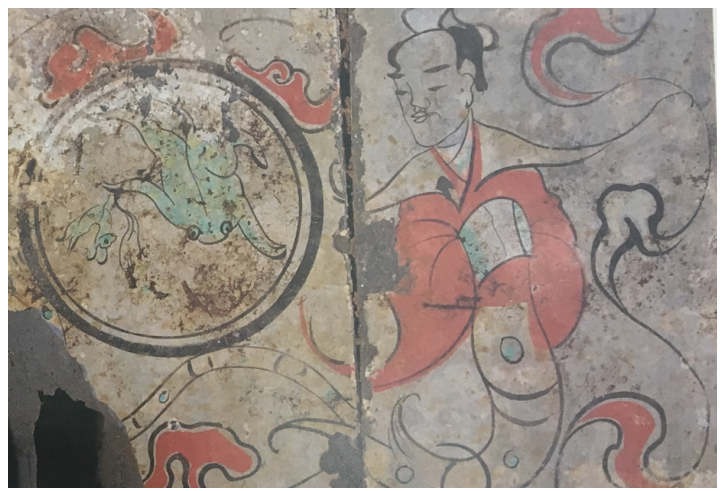

Figure 15: Nüwa on the ceiling of the Qianjingtou tomb, Luoyang, Henan. First century BCE. Western Han (After Huang 1996, 85).
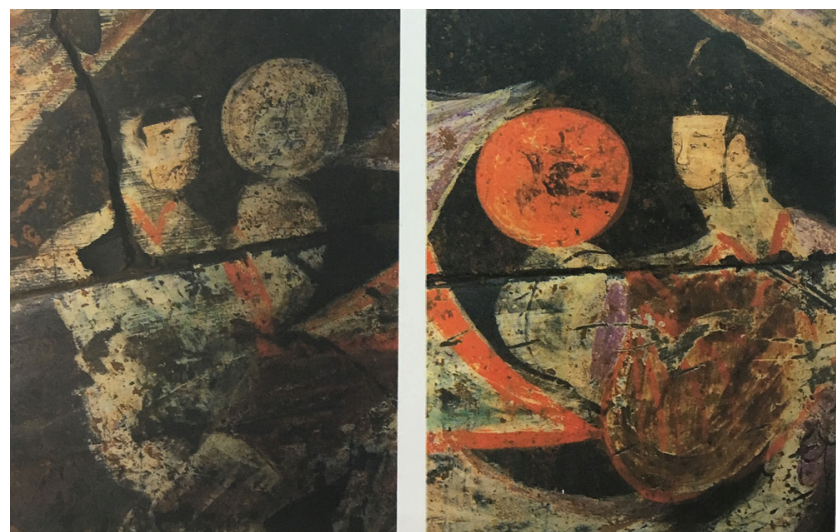

Figure 16: Fuxi and Nüwa of the Xincun tomb from Yanshi, Henan. First Century CE. Xin-Mang period (After Huang 1996, 126). 


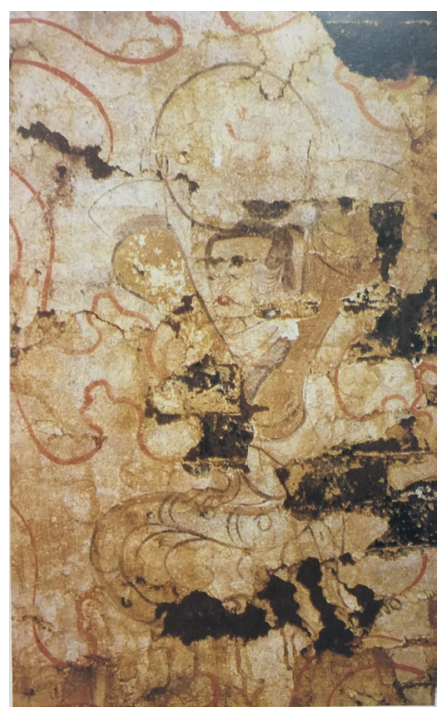

Figure 17: Changyi on the ceiling of the Daobei shiyouzhan tomb, Luoyang, Henan. Second century CE. Eastern Han (After Huang 1996, 148).

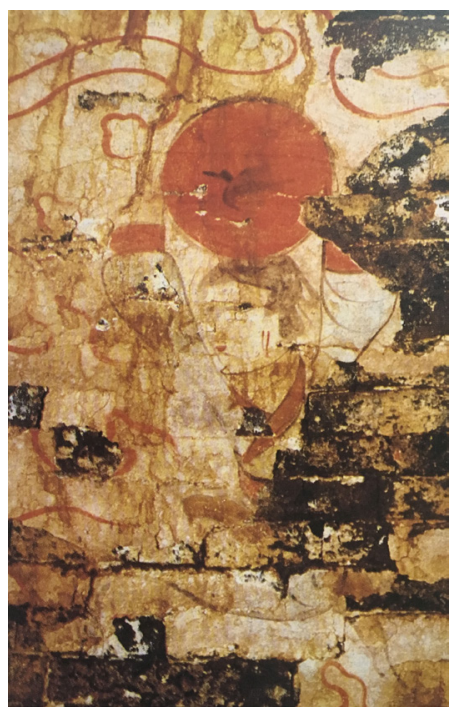

Figure 18: Xihe on the ceiling of the Daobei shiyouzhan tomb, Luoyang, Henan. Second century CE. Eastern Han (After Huang 1996, 147).

Nevertheless, this claim requires further discussion as it touches an issue that has been mentioned in some research but not yet addressed in detail: whether it is the 
pair of Fuxi and Nüwa, or Changyi and Xihe that are depicted in these tombs. Some research considers the couple depicted in the Xincun 辛村 tomb from the Xin-Mang period (Fig. 16) and the Daobei shiyouzhan 道北石油站 tomb of the Eastern Han in the second mode as Changyi and Xihe (Fig. 17, 18). ${ }^{5}$ In other words, it remains debatable about how to identify Fuxi and Nüwa in their formative stage during the Western Han Dynasty. Usually, figures were identified as Fuxi and Nüwa primarily because of their snake-like bodies, the symmetrical arrangement of them as a pair, or the attendance of the sun and the moon. However, the sun and moon could be associated with Changyi and Xihe, as Fuxi and Nüwa are not the only deities with snake-like bodies. Moreover, in the literary tradition, creatures with snake-like bodies are not explicitly associated with Fuxi and Nüwa. The silk manuscript from Zidanku 子彈庫 mentions that Fuxi looks like a dragon instead of a snake (Hunan sheng bowuguan 1974; Li 1985). Shanhaijing 山海經 (Classics of Mountains and Seas) records many creatures that feature a human-face and snakelike body. Nüwa and Xihe are just two of the many, and they are not in pair with any other male deities in most of these records (Yuan 1980, 230, 311).

Another issue involved in the identification of Fuxi and Nüwa is the origin of their combination into a couple. Although it was already a convention to render Fuxi and Nüwa as a couple, the origin of their combination remains debatable (Meng 2000; Hunan sheng bowuguan 1974; Li 1985; Liu 2006). According to textual sources, the two deities first appeared in Chinese mythologies compiled during the Warring States period, although remaining independent from each other. ${ }^{6}$ In the third century source Huainanzi, the two were mentioned for the first time in the same passage, but there is no particular description of their relationship (Liu 1989). The Eastern Han historian Ban Gu 班固 sees Nüwa as a subordinate official of Fuxi, while Zheng Xuan 鄭玄 raises Nüwa's status to the same of Fuxi, as one of the sanbuang 三皇 (Three Sovereigns). Mainstream scholarship on Fuxi and Nüwa usually cites Huainanzi, and attributes the combination of the pair to the social and religious transformation that was taking place during the Han Dynasty, which aimed to pair female deities with male companions. ${ }^{7}$ Currently, there

5 In Huang (1996) murals from Bu Qianqiu tomb and Qianjingtou tomb were identified as showing Fuxi and Nüwa, while the others as Changyi and Xihe. Liu (2006) follows this identification.

6 Fuxi is mentioned primarily in Zhuangzi 莊子, Xunzi 荀子, Chuci 楚辭, and Zhanguoce 戰國策. Nüwa appeared in Shanhaijing 山海經, Liji 禮記, and Chuci 楚辭.

7 Regarding how Fuxi and Nüwa were transformed into a pair, various theories have been proposed. The most agreed theory attributes the origin of the two deities' union to the transformation from a matriarchal to patriarchal society. The same transformation happens to Xiwangmu (Queen Mother of the West) as well. Xiwangmu first symbolises eternal happiness in the realm of immortals as an individual goddess, but was later absorbed into the emerging Taoist pantheon and paired with Dongwanggong 東王公 (King Father of the East) (Wu 1989; Yang 1999). 
are two main theories concerning the origin of the two deities' combination. The first argues that the two deities did not appear as a couple until the Tang Dynasty. A large number of the supposed depictions of the couple with intertwined snake tails during the Han Dynasty are thus not Fuxi and Nüwa, but merely an anthropomorphic representation of yin and yang. The second theory pushed the union of the pair back to the Warring States period of the third century BCE, according to passages that mention Fuxi and his wife Nühuang 女皇 (Nüwa) recorded in the Zidanku silk manuscript from a Chu 楚 tomb.

Regarding the current debate on the identification of the two deities, I propose three additional perspectives. The first relies on epigraphical sources while the other two are based on the modes of depicting the sun and moon, as concentrated in this research. The most reliable evidence for iconographic identification actually entails inscriptions. Currently, all of the three Fuxi and Nüwa images bearing epigraphical references to the two deities are dated to the Eastern Han. They were found respectively on a stone sarcophagus from Guitoushan 鬼頭 山 at Jianyang 簡陽, Sichuan (Fig. 19), on a pictorial panel from the Wu Liang Shrine 武梁祠 at Jiaxiang 嘉祥, Shandong (Fig. 1), and on the ceiling of a tomb from Jingbian 靖邊, Shaanxi (Fig. 20) (Shaanxi sheng kaogu yanjiuyuan 2017). As all inscriptions were dated to the Eastern Han Dynasty, later than the Western Han tomb paintings in the Luoyang area, they are not sufficient to indicate a solid, exclusive connection between snake-like bodies and Fuxi and Nüwa in Luoyang tombs.

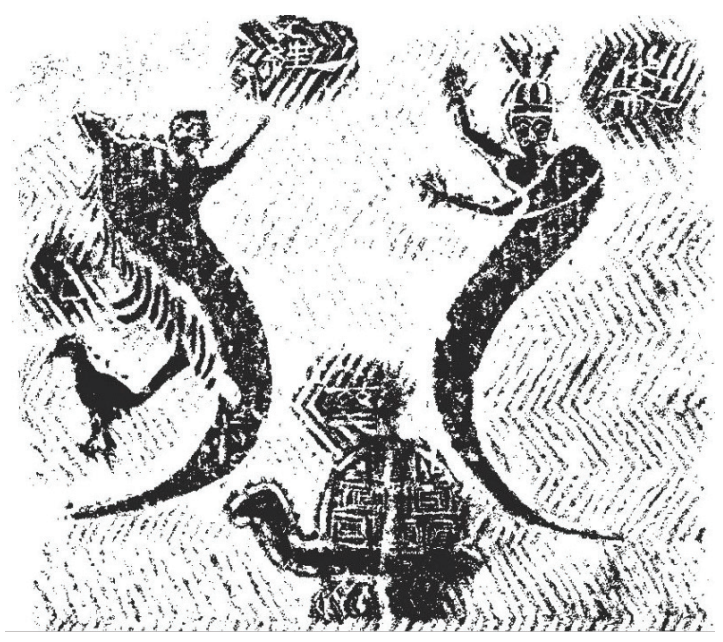

Figure 19: Fuxi and Nüwa on the no. 3 sarcophagus of the Guitoushan tomb. Rear end. Jianyang, Sichuan. Second century CE. Eastern Han (After Henan meishu chubanshe 2000, fig. 100). 


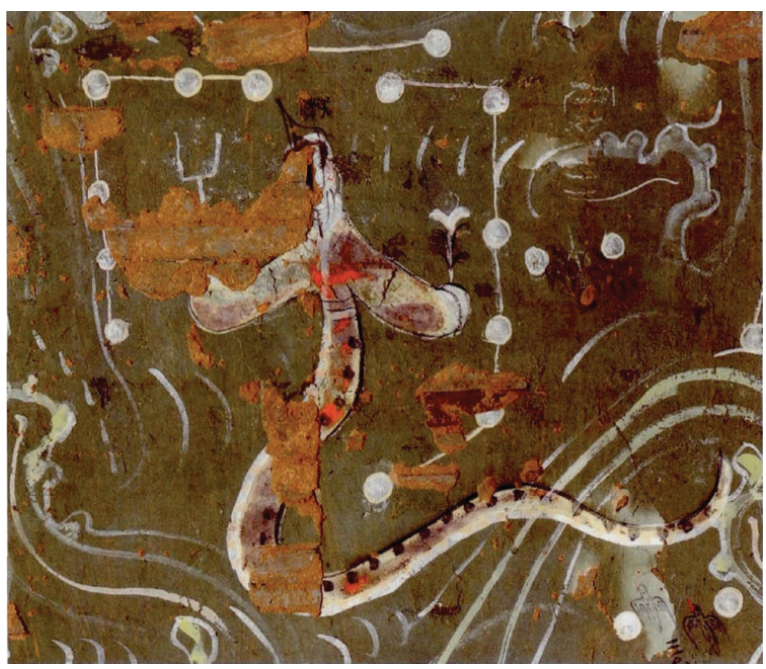

Figure 20: Fuxi in the celestial world. Jingbian, Shaanxi. Second century CE. Eastern Han (After Shaanxi sheng wenwu kaogusuo 2017, fig. 41).

Second, a thorough survey of the depiction of the sun and moon in connection to Fuxi and Nüwa in the Luoyang area indicates that previous scholarship is problematic in terms of distinguishing the imagery of Fuxi and Nüwa from that of Changyi and Xihe. Previous scholarship proposed an exclusive identification of the paired deities in the Bu Qianqiu tomb (Fig. 3), Qianjingtou tomb (Fig. 14, 15), and most of the Eastern Han tombs as Fuxi and Nüwa, while the pair in the Xincun tomb (Fig. 16) and the Daobei shiyouzhan tomb (Fig. 17, 18) were identified as Changyi and Xihe merely because of the distinctive ways how the sun and moon were depicted (Huang 1996). If based on the four modes identified in current research, the supposed Fuxi and Nüwa refers to the first mode while Changyi and Xihe to the second. However, this absolute distinction contradicts the fact that the second mode was also applied in other Luoyang murals that were identified as representations of Fuxi and Nüwa and dated to a period similar to the Xincun tomb and the Daobei shiyouzhan tomb. In addition, the identification in previous studies did not interpret the chronological sequence of the two modes. Why was the pair of Changyi and Xihe depicted later than Fuxi and Nüwa?

Third, previous identifications ignore an element that is essential for an iconographic study: the two deities depicted in murals of the Western Han Qianjingtou tomb are both males, in terms of their plain dresses, bold foreheads and the same hairstyle (Fig. 14, 15), while in the Luoyang Han tomb paintings an ordinary female figure typically wears headdresses and features a hairstyle that symmetrically separates the 
bangs into two parts. Thus the current identification of the pair in the Western Han Qianjingtou tomb became problematic, because it is never in doubt that Nüwa is a female goddess. The same problem also appears in the Eastern Han Xincun tomb (Fig. 16), which depicts both the figures wearing an official hat that is only seen on males. Without more evidence for making any further interpretations, definitive answers to the identification issue are perhaps still beyond our reach. However, the notable gender differences discussed above should not be ignored in future research. At the very least, the current evidence suggests that there were two pairs of deities, one pair of a male and a female, while the other of two males, both incorporated the sun and moon in their imagery at the same time.

\section{The Second Mode and its Celestial World: Interpreting Regional Differences in the Depiction of Fuxi and Nüwa during the Eastern Han Dynasty}

In the Luoyang area during the Eastern Han Dynasty, it became a standard way to depict a pair of deities in the second mode, which has the sun and moon held upwards by the deities. This mode was also widely applied in other burial centres, including Nanyang (Fig. 8), and the Southwest region (Fig. 2), but not in Shandong/Jiangsu. In the Southwest region, Fuxi and Nüwa are widely depicted on stone sarcophagi, while in Nanyang it is the pictorial stones and bricks that are employed as the primary media. Stone sarcophagi and shrines appeared in China during the period from the second century BCE to the early third century $\mathrm{CE}$ in two regions, the Shandong/Jiangsu region on the East Coast and the Southwest region, as an outcome of the transformative wave of the ritual and burial traditions after Emperor Wu's 漢武帝 reformation. During the early stage, images were engraved in thick lines with simple motifs and patterns. Later, more diverse subject matters developed (Jiang 2001; Wu 2012).

In Shandong/Jiangsu, Fuxi and Nüwa in most cases hold a square and compass respectively (Fig. 1). In the Southwest region, Fuxi and Nüwa are primarily depicted in two ways: the first has them hold the sun and moon (Fig. 2), and the second they hold the square and compass in addition to the sun and moon. The first type appears earlier and flourishes in a broader area than the second. It could thus be interpreted that the motif of the square and compass was a later addition to the local tradition of representing Fuxi and Nüwa. The possible source is the Shandong/Jiangsu area, where the square and compass are the dominant motifs employed in the imagery of Fuxi and Nüwa (Fig. 1). The concepts of the square and compass could be associated with the natural forms 
of circle and square. In traditional Chinese cosmology the earth was square and the heavens round, and thus Fuxi holds a set square to draw the former, and Nüwa a compass to draw the circle of the Earth (Whitfield and Sims-Williams 2004, 329). Some scholars propose that these symbols were used to represent cosmic order, a link between heaven and earth, and a favourite environment for the deceased (Lewis 1999, 204).

In Nanyang, the couple sometimes holds the sun and moon (Fig. 8), but in most cases both of them hold lingzhi (Fig. 7). Since cases from the Southwest region are dated relatively later than those from Shandong/Jiangsu and Nanyang, it is possible that the tradition of depicting the pair of the sun and moon as well as that of the square and compass upheld by Fuxi and Nüwa in the Southwest area is a synthesis of influences from multiple areas, including Luoyang, Shandong/ Jiangsu and Nanyang.

How should we perceive the different regional traditions and reconstruct their connections? One angle is to analyse the different cultural information conveyed in pictorial and compositional schemes in each region. No matter whether it is the pair of Fuxi and Nüwa, or Changyi and Xihe, the paired deities with snake-like bodies found in Han tombs from the Luoyang area were interpreted as celestial figures that constitute a heavenly realm. In contrast, the arrangement of the paired deities as part of the celestial world is not prominent in the Shandong and Nanyang areas. The depiction from the Wu Liang shrine in Shandong is located on the second panel of the wall in the second room (Fig. 1). Among Nanyang representations of Fuxi and Nüwa, most are located in the middle part of the vertical slab that supports the structure of stone sarcophagi. The couple is usually arranged above or below door attendants, hunting scenes, or auspicious animals, and sometimes repeatedly appear on one sarcophagus (Fig. 7). Another distinction is the way how the tails of the two deities are arranged. Luoyang tombs tend to have the two separated from each other, while in Shandong/Jiangsu and Nanyang most examples have their tails intertwined. Among Nanyang examples, the couple's tails are intertwined, specially together with the image of Xuanwu 玄武, when they were located on the same stone slab (Fig. 7), unless they are separated symmetrically to two door-slabs (Figs. 10). A similar pattern appears in Shandong/Jiangsu area as well (Figs. 1, 9). In brief, a comparison of the location of the paired deities in the Luoyang, Shandong and Nanyang areas reveals two distinctive groups: Luoyang tombs depict the paired deities in a celestial realm together with the sun and moon, while in the Shandong and Nanyang areas the sun and moon are not essential motifs to the imagery of Fuxi and Nüwa, since the couple is not always located in the celestial realm, and there is also the relative popularity of other motifs, including lingzhi, the square and compass. 


\section{The Third Mode: Incorporating the Shandong and Shaanxi Traditions of Depicting the Square and Compass}

As briefly mentioned above, the third mode, which has the sun and the moon embraced by Fuxi and Nüwa respectively, already appeared during the Han Dynasty in Shandong/Jiangsu (Fig. 9), Nanyang (Fig. 10) and Shaanxi (Fig. 11), but never became the dominant mode. When it comes to the Wei-Jin period, the third mode began to replace the second as the most popular one. The majority of WeiJin tombs were discovered near the major cities of Dunhuang 敦煌, Jiuquan 酒 泉, Jiayuguan 嘉峪關, and Zhangye 張掖. The motifs of Fuxi and Nüwa became more popular in Wei-Jin tombs in comparison to the Han period, but their locations and styles show notable new features. While the Han tombs have the pair depicted on ceilings or upper walls in Luoyang and Shandong/Jiangsu, on the rear end or sides on sarcophagi in the southwest region, and door slabs in Nanyang, the majority of Wei-Jin tombs depict the pair on the inner side of the timber coffin cover (Fig. 12) or pictorial bricks on walls and ceilings (Fig. 5). One theory considers the origin of depicting the pair on coffin covers as a simplification of the practice of covering the coffin lid with Jingming 旌銘 (banner) practiced since the pre-Qin period and after (Liu 2006, 147-48).

Among the surviving examples found on coffin covers, the pair is arranged in two basic types: the first type horizontally locates Fuxi and Nüwa on two ends (Fig. 12), and the second depicts the two vertically facing each other (Fig. 4) (Kong and Hou 2006). It is noticeable that for the first type, the overall design of Fuxi and Nüwa recalls the design on ceilings and upper walls in Han tombs from the Luoyang area. An examination of the historical context of Hexi during the WeiJin era provides a connection between the two regions: it was from the Western Han period on that a mass migration along with cultural transmission from the Central Plain to the Hexi Corridor took place. However, the Han tradition of applying the first and the second modes to depict the sun and moon was not inherited by these Wei-Jin burials in the horizontal type. The majority applied the third mode of depicting the sun and moon, which has them embraced by Fuxi and Nüwa respectively (Fig. 12). Tombs in the second type, which arrange the two deities on coffin cover vertically, began to employ the fourth mode, which has the sun arranged above the couple with the moon below (Fig. 4). To sum up, it is firstly at the Wei-Jin Hexi Corridor that the fourth mode came into view, while the third mode became predominant.

One possible answer to the appearance of the third mode at Hexi is the movement of immigrants from the Shandong and Shaanxi areas. The Eastern Han case from Shandong (Fig. 9) and that from Shaanxi (Fig. 11) are distinctive from the 
one from Nanyang (Fig. 10), as the latter tradition never depicts the square and compass as attributes of the two deities, while the former two areas have the pair of attributes always in together with the sun and moon (Kong and Hou 2006). In Wei-Jin pictorial bricks and coffin paintings, the sun and moon are always in combination with the pair of the square and compass. To push this discovery further, the Shandong tradition exerts a more explicit influence on the Wei-Jin tomb art, since they both depict the two deities with dragon-like bodies, as well as similar ratios regarding the size of the sun and moon and the deities' bodies.

\section{From Nanyang to the Southwest: the Confluence of the Fuxi and Nüwa Imagery and the Formation of the Sun God and Moon Goddess}

Besides being depicted in association with the imagery of Fuxi and Nüwa, the sun and moon have already been widely represented in a variegated range of pictorial contexts. An examination of the visual tradition of depicting the two celestial bodies during the Han and Wei-Jin period reveals an idiosyncratic phenomenon in the Southwest: the appearance of the anthropomorphic rendering of the sun and moon as a pair (Fig. 13, 21, 22, 23). A further inquiry indicates that the formation

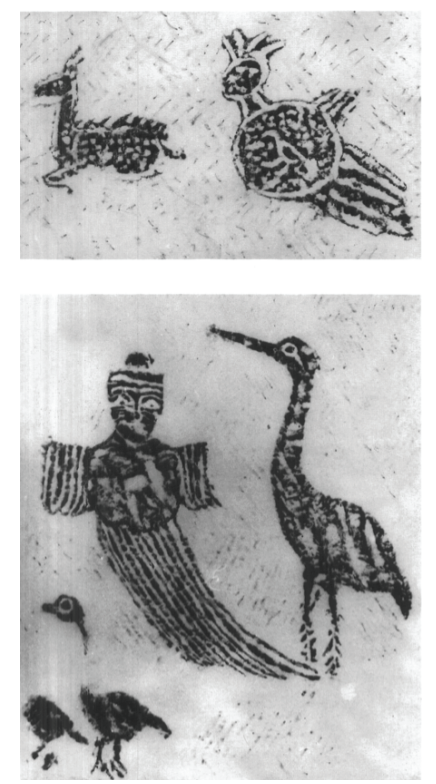

Figure 21: Sun God and Moon Goddess on No. 4 and No. 5 tomb of Guitoushan, Jianyang, Sichuan. Second century CE. Eastern Han (After Gong 1998, figs. 348 and 349). 
of the sun and moon in anthropomorphic representation in the Southwest incorporated two visual traditions: that of Fuxi and Nüwa in local tradition, since the sun and moon appear in anthropomorphic form with a rendering of their heads and faces almost identical to that of Fuxi and Nüwa, and that of the sun and moon in Nanyang, where we see the prototype of the Southwest composition for locating the sun and moon as part of a flying figure's body (Fig. 24 and 25).

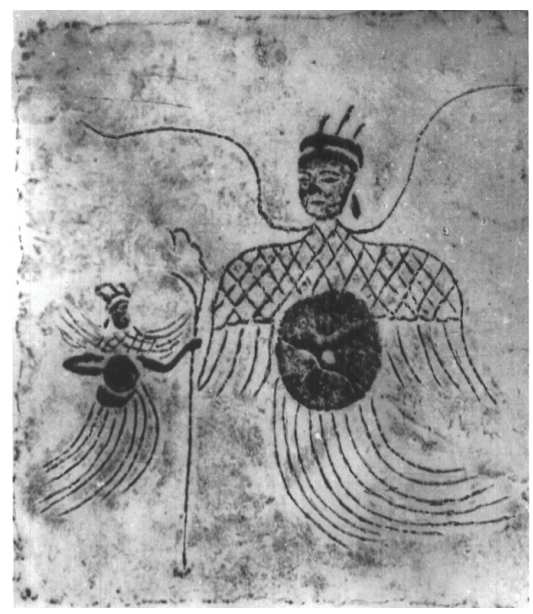

Figure 22: Sun God and Moon Goddess from the tomb of Zhaojue Temple, Chengdu, Sichuan. Second century CE. Eastern Han (After Gong 1998, fig. 345).
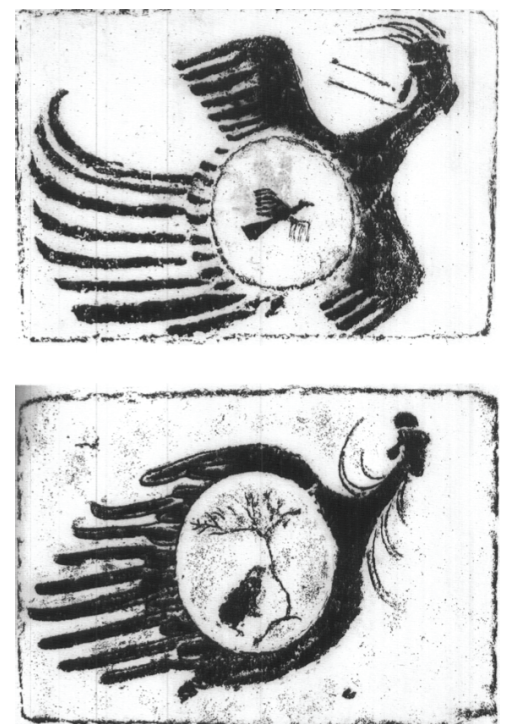

Figure 23: Sun God and Moon Goddess from the tomb of Xinfan, Sichuan. Second century CE. Eastern Han (After Gong 1998, figs. 346 and 347). 


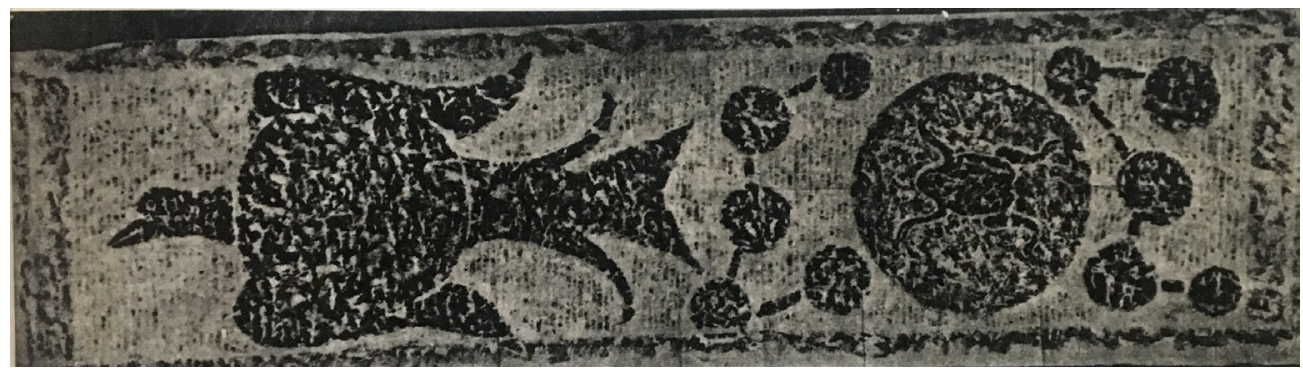

Figure 24: The sun and the moon from Nanyang, Henan. Second century CE. Eastern Han (After Wang and Shan 1990, fig. 280).

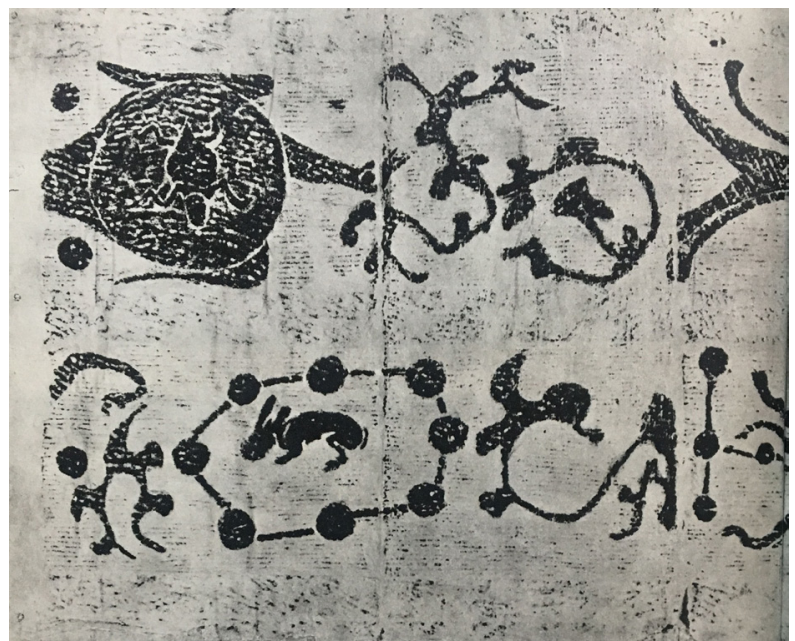

Figure 25: The moon disc embraced by a bird. Nanyang, Henan. Second century CE. Eastern Han (After Wang and Shan 1990, fig. 275).

The No. 3 sarcophagus from Guitoushan 鬼頭山, Jianyang 簡陽, discussed above, and which depicts Fuxi and Nüwa with inscriptions (Fig. 19), has its right and left sides carved. Its left side shows two flying figures with human-faces but bird-like bodies (Fig. 13). The left deity has its torso formed in the shape of the sun and the right deity in the shape of the moon. Surviving inscriptions between the two figures reveal that they are $R i$ 日 and Yue 月. Similar depictions of the sun and the moon have been found on the two other stone sarcophagi from Guitoushan (Fig. 21), as well as on a number of others from the Southwest, such as the Eastern Han tomb at the Temple of Zhaojue 昭覺寺 in Chengdu (Fig. 22), and the brick tomb from Xindu 新都, Xinfan 新繁 (Fig. 23). All of these examples depict the moon and sun as part of the bodies of figures that have human faces with 
bird-like bodies. In addition, they appear with explicit gender differences: the sun god features a mountain-shaped crown and the moon goddess has a feather-like headdress. The Xinfan case (Fig. 23) depicts a bird inside the orb-shaped body of the sun and a toad in that of the moon. The Guitoushan case (Fig. 21) follows the same manner, although rendered relatively roughly. The Zhaojue case (Fig. 22) merely adorns the sun god with a bird, and also varies from the other cases in terms of the difference in size between the sun and moon.

It is interesting that this anthropomorphic representation of the sun and moon is not applied in any other sites, but only in the Southwest. Even more notable is that their facial features and headdresses are treated exactly the same as those of Fuxi and Nüwa: the mountain-shaped crown for the male, while a feather-like headdress for the female. One may argue that a similar treatment of the paired deities is also identifiable in the case of Dongwanggong (King Father of the East) and Xiwangmu (Queen Mother of the West). However, the Dongwanggong was not seen in the southwest during the Han period. Furthermore, the sun and moon appear in a pair since the beginning, while Dongwanggong was a later creation for making a couple with Xiwangmu, the long-existing deity that has a specific significance in Chinese mythology and already had a long history of transformation by the Eastern Han, when Dongwanggong was created (Wu 1989, 108-41; Gong 1998, 345-77). Thus the tradition of depicting Fuxi and Nüwa is more likely the source for the formation of the sun and moon in an anthropomorphic couple.

To examine the current argument, I further explored the tradition of depicting the sun and moon in other areas during the Han Dynasty, and found that the Nanyang area shares a similar composition with the Southwest, which renders the sun and moon as part of the bodies of flying figures. The majority of the Nanyang examples show the sun depicted as embraced by a bird, while the moon appears just like an ordinary disc within which is a toad or hare (Fig. 24). But it is notable that the moon disc with a toad was gradually transformed into part of a flying bird, in symmetry with the sun-bird. The bird is very likely the crow that is conventionally depicted within the sun. The way that the bird is depicted is no different from the three-legged crow represented within the sun disc from the Han Dynasty.

Now if we turn to the tradition of representing the sun and moon in anthropomorphic form in the Southwest (Figs. 13, 21, 22, 23), the composition and iconography are no different from the Nanyang tradition (Fig. 25), except for their human faces. In other words, the practice of depicting the sun and moon embraced or as part of the bodies of a bird already became popular in the early Eastern Han Dynasty in Nanyang. As it turns to the later Eastern Han, the Nanyang tradition, together with the already established tradition that depicts Fuxi and Nüwa in a 
gender-discernible pair, provided sources for the creation of the anthropomorphic representation of the sun and moon in the Southwest. Nevertheless, it is difficult to reach any absolute conclusions with regard to the motivation for the creation of the anthropomorphic sun and moon, just like the long-debating issue regarding the creation of the anthropomorphic Buddha images. This requires further research on the overall historical, cultural, and visual landscape of the Southwest during the Han Dynasty.

\section{Eastern Han Nanyang: Fuxi and Nüwa as Representatives of Fertility}

As indicated above, the sun and moon were never the dominant attributes in the Nanyang depiction of Fuxi and Nüwa, but developed more extensively as celestial orbs that usually appear amidst constellation diagrams. Derivative but necessary to address, through the examination of the essential features of the Fuxi and Nüwa imagery created in different regions during the Han Dynasty, it is explicit that the tradition of the Nanyang area is much more distinctive and diverse than that of other regions. In addition to the preference for lingzhi in Nanyang, another trait is the incorporation of Xuanwu (Dark Warrior) in the imagery of Fuxi and Nüwa. Xuanwu is one of the four mythological animals that are typically termed Sishen 四神 (four deities), each guarding one of the four cosmic directions and four seasons (He 1998, 183-88; Wang 1995). They are Qinglong 青龍 (blue dragon), Baibu 白虎 (white tiger), Zhuque 朱雀 (red bird), and Xuanwu 玄武 (Dark Warrior). Xuanwu is the guardian of the north, the utmost point of the yin. On the pictorial stone slab from Xinye 新野 Lihu 禮湖 at Nanyang, Fuxi and Nüwa are located facing each other with their bodies intertwined over a Xuanwu at the bottom. It is identifiable through the inscription above it, and its appearance in the conventional rendering of a Xuanwu as a tortoise encircled by a snake (Fig. 7). Xinye Lihu is not the first case of representing Xuanwu together with Fuxi and Nüwa in Nanyang, but the combination is not standardised. On another pillar from the same tomb, the paired deities are represented in a way that is same but without Xuanwu.

It is clear that Xuanwu's natural connection to the north and the winter does not constitute a satisfactory answer here. The location of the configuration in the Xinye Lihu tomb of Nanyang has no directional reference, but instead as one of a group of motifs on one stone slab. The current identification tends to explain the appearance of Xuanwu as a counterpart of a Giant figure which forms another tradition of the genesis mythology and fertility (Wang 1990). Even without 
referring to the Giant figure, it is also legitimate to perceive the connection between Xuanwu and fertility according to Xuanwu's trait of representing yin. In addition, both visual and textual traditions reveal that Xuanwu has not been fixed as one of the Sishen until the late Eastern Han. A more conservative interpretation of the combination of Xuanwu with Fuxi and Nüwa is the snake part of Xuanwu's iconography. In extant depictions of Xuanwu in combination with Fuxi and Nüwa, the snake part of the Xuanwu is at the same time the lower body of the two deities. Thus it is this resemblance makes it possible to have Xuanwu visually connected with other snake- or dragon-like creatures.

\section{The Development of the Fourth Mode in the Hexi Corridor Since the Wei-Jin Era}

Finally, the fourth mode depicts the sun above Fuxi and Nüwa with the moon below (Fig. 4, 6), naturally in a vertical setting. Although most surviving materials showing this mode are silk or hemp paintings and banners found in Turfan burials dated to the Tang Dynasty from the sixth to seventh centuries (Fig. 6), the prototype of the fourth mode already appeared in the Wei-Jin era, from the third to fifth centuries, on the coffin covers in Jiayuguan burials (Fig. 4).

Considering the focus of this article is the period between Han and Wei-Jin, I will not delve into the discussion regarding the formation nor the function of the fourth mode in Tang funerary paintings (Stein 1928; Xinjiang Weiwuer zizhiqu bowuguan 1972; Uyeno 1974; Whitfield 1985; Chen 2001). But it is worth presenting several discoveries based on a preliminary comparison of the fourth mode between the Wei-Jin example and the successive Tang paintings.

First is the distinction in the overall setting of the painting between Wei-Jin Jiayuguan and Tang Turfan. In the Wei-Jin case (Fig. 4), the two deities are surrounded by mountain ranges, which on two sides have peaks facing outwards, while a group of Tang banners fill the surrounding space with scattered constellation diagrams (Fig. 6). The Tang banners' interest in celestial symbols also shows in the way that the sun and moon discs were rendered abstractly: the sun appears with radiating beams inside and moon in the crescent shape. Furthermore, some even have the orbs surrounded by a ring of stars.

Second is the replacement of the traditional rendering of the two deities' headdresses with a new mode in Tang banners. The Wei-Jin example inherited the convention of rendering Fuxi with a mountain-shaped hat and Nüwa with a crown, while in all of the Tang paintings Fuxi began to feature an ordinary official cap, while Nüwa a plain knot. Both the figures appeared more human-like, in 
comparison to the divine treatment of their predecessors from the Han to WeiJin. In addition, they dress in short pleated tunics.

The third discovery is regarding the origin of the vertical arrangement of the sun above with the moon below. One may argue that this type is done to deal with the limitations of the chamber or the silk banner's elongated rectangular shape, although I believe that it is not sufficient to attribute the motivation to spatial concerns alone. Here I come up with a hypothesis that the arrangement of the sun and moon on the ends of a vertical space in the fourth mode might be related to the tradition of representing the sun god and wind goddess at the two ends of the central strip on the ceiling in Buddhist cave-temples at Kizil, which is on the northern branch of the Silk Road. But a concrete conclusion requires a further examination of cave-temple arts before making any further arguments. This hypothesis is also based on the importance of celestial symbols for both the Turfan silk paintings and the central strip paintings in Buddhist cave-temples (Ma 1996; Zhu 2003). In brief, the Tang silk paintings show a clear departure from the traditional depiction of Fuxi and Nüwa, however they have certainly been influenced by the Wei-Jin conventions due to the same way in which they render the sun and moon in the fourth mode.

\section{Conclusion}

Instead of proposing an integrated narrative of the evolutionary history of the Fuxi and Nüwa imagery, this research starts with a pre-iconographic study of the visual materials that we have at hand. Putting the primary emphasis on the description and classification of the Fuxi and Nüwa imagery in terms of how the sun and moon are incorporated, I identified four primary modes and discussed their historical and regional features. Further examination and analysis of each mode contributed to the current field by providing new perspectives for readdressing some issues that remain underexplored, and bringing back to the field several pictorial traditions that should not be neglected in the study of the Fuxi and Nüwa worship.

This study challenges the over-absolute identification of the earliest representation of Fuxi and Nüwa in a pair, and that of Changyi and Xihe, another set of paired deities recorded to be in close relation to the celestial world, in Western Han mural tombs from the Luoyang area. The relatively late date of the Eastern Han, when the earliest epigraphical texts referring to Fuxi and Nüwa and other textual and historical sources were dated to, leave open the question as to when Fuxi and Nüwa were formed into a pair, and when they were represented together with the sun and moon, and this thus requires further research. Instead of identifying the paired deities with snake-bodies as Fuxi and Nüwa, or Changyi and Xihe, 
based on undemonstrated distinctions in visual or textual traditions, the present research suggests a shift of focus to the recognisable distinctions in visual details. These differences include the shift from depicting the sun and moon in the first mode to the second upon the beginning of the Eastern Han, and the masculine appearances of both the deities depicted in the Western Han Qianjingtou tomb.

Second, regional variations significantly portray the development of each mode. While the first mode was only seen in the Luoyang area, the second mode prevails in the entire northern areas during the Han Dynasty, and kept on flourishing during the Wei-Jin era. The third mode appeared in the Eastern Han, but did not flourish until the Wei-Jin era in Hexi. Although its origin cannot be absolutely ascertained, its noticeable co-existence with the pair of the compass and square alludes to its close connection to the tradition of Shandong and Shaanxi. The fourth mode was not seen beyond the territory of the Hexi Corridor, from its appearance in Wei-Jin era and its later flourishing in funerary banners during the Tang Dynasty. Further examinations reveal more complicated interactions between different regions and exchanges of motifs with other imagery. The local tradition of depicting Fuxi and Nüwa, together with that of the depiction of the sun and moon in Nanyang, has been incorporated with the formation of the sun and moon in the anthropomorphic representations seen in the southwest.

Finally, a thematic research is defined by information retrieved from materials, rather than the use of a later-created terminology. Instead of making absolute identifications, it is more significant to organise the surviving materials through detailed examinations of each visual element. In addition, an iconographic study of images without the consideration of their original contexts will muddy the waters with its over-imposed set of classifications.

\section{References}

Ban, Gu 班固. 1962. Han shu 漢書 (History of the Western Han). Beijing: Zhonghua shuju.

Birrell, Anne. 1993. Chinese Mythology: An Introduction. Baltimore and London: Johns Hopkins University Press.

Chen, Changshan 陳長山. 1987. “Gaomei huaxiang xiaokao 高謀畫像小考 (A Study of the Image of Gao Mei).” Kaogu yu wenwu 考古與文物 5: 57.

Chen, Liping 陳麗萍. 2001. "Guanyu Xinjiang Asitana-Halahezhuo diqu chutu de Fuxi Nüwa huaxiang ji yixie wenti de tantao 關於新疆阿斯塔納一哈拉 和卓地區出土的伏羲、女媧畫像及一些問題的探討 (Regarding the Paintings of Fuxi and Nüwa Discovered from the Astana and Khara-khoja Area of Xinjiang).” Dunbuang xue jikan 敦煌學輯刊 1: 63-77. 
Dai, Chunyang 戴春陽. 1998. Dunbuang Foyemiao wan: Xijin huaxiang zhuanmu 敦煌佛爺廟灣: 西晉畫像磚墓 (Dunhuang Foyemiao Wan: Pictorial Brick Burials of Western Jin). Beijing: Wenwu chubanshe.

Deng, Wenkuan 鄧文寬. 2010. “Tulufan chutu 'Fuxi Nüwa huafan' kaoxi 吐魯番 出土“伏羲女媧畫幡”考析 (A Study of the Fuxi and Nüwa Paintings from Turfan)." In Zhang Guangda xiansheng bashi huadan zhushou lunwenji 張廣達 先生八十華誕祝壽論文集 (Proceeding for the Celebration of Professor Zhang Guangda's Eightieth Birthday), 881-900. Taipei: Xin wenfeng chuban gongsi.

Dunhuang shi bowuguan 敦煌市博物館. 2017. Dunhuang shi bowuguan guancang zhengui wenwu tulu 敦煌市博物館館藏珍貴文物圖錄 (Catalogue of Collections in the Dunbuang Municipal Museum). Shenyang: Wanjuan chubanshe.

Fan, Ye 范晔. 2007. Hou Han shu 後漢書 (History of the Eastern Han). Beijing: Zhonghua shuju.

Gansu sheng wenwudui 甘肅省文物隊, Gansu sheng bowuguan 甘肅省博物館, and Jiayuguan wenwu guanlisuo 嘉峪關文物管理所. 1985. Jiayuguan bibua mu fajue baogao 嘉峪關壁畫墓發掘報告 (Reports on the Excavation of Mural Tombs from Jiayuguan). Beijing: Wenwu chubanshe.

Gao, Wen 高文. 1998. Sichuan Handai shiguan huaxiang ji 四川漢代石棺畫像 集 (A Catalogue of Sichuan Pictorial Sarcophagi of the Han Dynasty). Beijing: Renmin meishu chubanshe.

—, ed. 2000. Zhongguo huaxiangshi quanji 7: Sichuan Han huaxiangshi 中國畫 像石全集 7: 四川漢畫像集 (Chinese Pictorial Stones 7: Han Pictorial Stones from Sichuan). Zhengzhou: Henan meishu chubanshe.

Gong, Tingwan 龔廷萬, Gong Yu 壟玉, and Dai Jialing 戴嘉陵, eds. 1998. Ba Shu Handai huaxiang ji 巴蜀漢代畫像集 (Pictorial Han Art from Ba and Shu). Beijing: Wenwu chubanshe.

Guo, Wenying 過文英. 2007. "Lun Han mu bihua zhong de Fuxi Nüwa shenhua 論漢墓壁畫中的伏羲女媧神話 (The Mythology of Fuxi and Nüwa in Han Murals).” PhD thesis, Zhejiang University.

Han, Wei 韓偉. 2000. Shaanxi Shenmu Dabaodang Han caibui huaxiangshi 陝西 神木大保當漢彩繪畫像石 (The Han Pictorial Stone of Dabaodang, Shenmu, Shaanxi). Chongqing: Chongqing chubanshe.

$\mathrm{He}$, Ning 何寧, ed. 1998. Huainanzi jishi 淮南子集釋 (Huainanzi and Collected Commentaries). Beijing: Zhonghua shuju.

He, Xilin 賀西林. 2001. Gumu danqing: Handai mushi bibua de faxian yu yanjiu 古墓丹青: 漢代墓室壁畫的發現與研究 (Paintings in Ancient Tombs: Discoveries and Studies of Mural Paintings of the Han Dynasty). Xi'an: Shaanxi renmin meishu chubanshe (1st edition 2001).

Huang, Minglan 黃明蘭, and Guo Yinqiang 郭引強. 1996. Luoyang Han mu bibua 洛陽漢墓壁畫 (Murals in Han tombs from Luoyang). Beijing: Wenwu chubanshe. 
Huang, Yafeng 黃雅峰, and Chen Changshan 陳長山. 2008. Nanyang Qilin'gang Han huaxiang shimu 南陽麒麟崗漢畫像石墓 (Pictorial Stone Tomb at Qilingang, Nanyang). Xi'an: San qin chubanshe.

Hunan sheng bowuguan 湖南省博物館. 1974. “Changsha Zidanku Zhanguo muguo mu 長沙子彈庫戰國木槨墓 (The Timber Coffin Tomb of the Warring States Period from Zidanku at Changsha)." Wenwu 文物 2: 36-43.

Jiang, Yingju 蔣英炬, ed. 2000. Zhongguo huaxiangshi quanji 1: Shandong Han huaxiangshi 中國畫像石全集 1: 山東漢畫像集 (Chinese Pictorial Stones 1: Han Pictorial Stones from Shandong). Jinan: Shandong meishu chubanshe.

Jiang, Yingju 蔣英炬, and Yang Aiguo 楊愛國, ed. 2001. Handai huaxiangshi yu huaxiangzhuan 漢代畫像石與畫像磚 (Pictorial Stones and Bricks from the Han Dynasty). Beijing: Wenwu chubanshe.

Jilin sheng bowuguan 吉林省博物館. 1964. “Jilin Jian Wukuifen sihao mu he wuhao mu qingli lüeji 吉林集安五盔墳四號墓和五號墓清理略記 (Notes on Tomb No.4 and No.5 at Wukui Burial, Jian, Jilin).” Kaogu 考古 2: 59-66. Jing, An 静安, ed. 1999. Gansu Gaotai Wei Jin mu caibui zhuan 甘肅高臺魏晉墓 彩繪磚 (Pictorial Bricks from Wei-Jin Tombs of Gaotai, Gansu). Chongqing: Chongqing chubanshe.

—, ed. 2000. Gansu Jiayuguan Wei Jin wu hao mu caibui zhuan 甘肅嘉峪關魏 晉五號墓彩繪磚 (Pictorial Bricks from Wei-Jin Tombs of Jiayuguan, Gansu). Chongqing: Chongqing chubanshe.

Kong, Lingzhong 孔令忠, and Hou Jingang 侯晉剛. 2006. "Ji xin faxian de Jiayuguan Maozhuangzi Wei Jin mu muban hua 記新發現的嘉峪關毛莊子魏晉 墓木板畫 (Recently Discovered Paintings on Timber Coffin from the WeiJin Period at Maozhuangzi, Jiayuguan).” Wenwu 文物 11: 75-85.

Lei, Jianjin 雷建金. 1988. "Jianyang xian Guitoushan faxian bangti huaxiang shiguan 簡陽縣鬼頭山發現榜題畫像石棺 (An Inscribed Pictorial Sarcophagus is Found at Guitoushan in Jianyang County).” Sichuan wenwu 四川文物 6: 65. Lewis, Mark. 1999. Writing and Authority in Early China. Albany: SUNY Press.

Li, Chenguang 李陳廣, Han Yuxiang 韓玉祥, and Niu Tianwei 牛天偉. 1998. “Nanyang Han dai huaxiang shimu fenqi yanjiu 南陽漢代畫像石墓分期研 究 (A Study of the Chronology of Han Pictorial Tombs from Nanyang).” Zhongyuan Wenwu 中原文物 4: 9.

Li, Ling 李零. 1985. Changsha Zidanku Zhanguo Chu boshu yanjiu 長沙子彈庫戰 國楚帛書研究 (A Study of the Chu Silken Manuscript from Zidanku, Changsha). Beijing: Zhonghua shuju.

Liu, Wendian 劉文典. 1989. Huainan honglie jijie 淮南鴻烈集解 (Interpreted Huainan Honglie). Beijing: Zhonghua shuju.

Liu, Wensuo 劉文鎖. 2006. “Fuxi Nüwa tukao 伏羲女媧圖考 (A Study of the Representation of the Fuxi and Nüwa).”Yishushi yanjiu 㙯術史研究 8:117-61. 
Liu, Zhao 劉昭. 1965. Hou Hanshu: Tianwen zhi 後漢書: 天文志 (History of the Later Han Dynasty: Astronomy). Beijing: Zhonghua shuju.

Luo, Erhu 羅二虎. 2002. Handai huaxiang shiguan 漢代畫像石棺 (Pictorial Sarcophagi of the Han Dynasty). Chengdu: Ba Shu shushe.

Luoyang bowuguan 洛陽博物館. 1985. “Luoyang Jinguyuan Xinmang shiqi bihuamu 洛陽金谷園新莽時期壁畫墓 (Luoyang Jinguyuan Mural Tomb from Xin Mang Period).” Wenwu cankao ziliao congkan 文物参考資料叢刊 9: $163-73$.

Luoyang bowuguan 洛陽博物館. 1977. “Luoyang Xi Han Bu Qianqiu bihuamu fajue jianbao 洛陽西漢卜千秋壁畫墓發掘簡報 (A Briefing of the Excavation of the Western Han Bu Qianqiu's Mural Tombs from Luoyang)." Wenwu 文物 6:1-12, 81-83.

Luoyangshi dier wenwu gongzuodui 洛陽市第二文物工作隊. 1993. “Luoyang Qianjingtou Xi Han bihuamu fajue jianbao 洛陽淺井頭西漢壁畫墓發掘簡 報 (A Briefing on the Excavation of Western Han Mural Tombs of Qianjingtou, Luoyang)." Wenwu 文物 5: 1-16, 97-100.

Luoyangshi di er wenwu gongzuodui 洛陽市第二文物工作隊. 2005. “Luoyang Yintun Xinmang bihuamu 洛陽尹屯新莽壁畫墓 (Luoyang Yintun Mural Tomb from Xin-Mang Period).” Kaogu xuebao 考古學報 1: 109-26.

Ma, Shichang 馬世長. 1996. “Kezier zhongxinzhu ku zhushi nei quanding yu houshi de bihua 克孜爾中心柱窟主室內券頂與后室的壁畫 (Paintings on Vaults and Back Chambers in Central-pillar Cave-temples at Kizil).” In Zhongguo shiku: Kezier shiku 中國石窟: 克孜爾石窟 2: 174-226. Beijing: Wenwu chubanshe.

Major, S. John. 1993. Heaven and Earth in Early Han Thought: Chapters Three, Four, and Five of the Huainanzi. Albany, NY: State University of New York Press.

Meng, Qingli 孟慶利. 2000. “Han mu zhuanhua Fuxi, Nüwa xiang kao 漢墓磚 畫伏義女媧像考 (Research on the Iconography of Fuxi and Nüwa in Han Pictorial Tombs).” Kaogu 考古 4: 81-86.

Nanyang shi bowuguan 南陽市博物館. 1981. Nanyang Handai huaxiang shike 南 陽漢代畫像石刻 (Han Pictorial Stones from Nanyang). Shanghai: Shanghai renmin meishu chubanshe.

Neijiang shi wenguansuo 內江市文管所, and Jianyang xian wenhuaguan 簡陽 縣文化館. 1991. “Sichuan Jianyangxian Guitoushan Donghan yamu 四川 簡陽縣鬼頭山東漢崖墓 (An Eastern Han Cave Burial at Guitoushan in Jianyang County in Sichuan)." Wenwu 文物 3: 20-25.

Shaanxi sheng kaogu yanjiusuo 陝西省考古研究所, and Xi'an Jiaotong daxue 西 安交通大學. 1991. Xi'an Jiaotong daxue Xi Han bihuamu 西安交通大學西 漢壁畫墓 (Xi'an Jiaotong University Western Han Mural Tomb). Xi'an: Xi'an jiaotong daxue chuban she. 
Shaanxi sheng kaogu yanjiusuo 陝西省考古研究所. 1997. “Shaanxi Shenmu Dabaodang di 11 hao, di 23 hao Han huaxiang shimu fajue jianbao 陝西神木大 保當第11號、第23號漢畫像石墓發掘簡報 (A Briefing on the Excavation of the no. 11 and no. 23 Han Pictorial Burials from Dabaodang, Shenmu, Shaanxi).” Wenwu 文物 9:26-35.

Shaanxi sheng kaogu yanjiuyuan 陝西省考古研究所, and Jingbian xian wenwu guanlichu 靖邊縣文物管理處. 2017. “Shaanxi jingbian xian Yangqiao pan Qushu hao Dong Han bihuamu fajue jianbao 陝西靖邊縣楊橋畔渠樹壕 東漢壁畫墓發掘剪報 (A Briefing on the Excavation of the Eastern Han Mural Tomb from Qushuhao, Yangqiao pan, Jingbian Villiage of Shaanxi).” Kaogu yu wenwu 考古與文物 1: 3-26.

Shandong sheng bowuguan 山東省博物館. 1982. Shandong Han huaxiangshi xuanji 山東漢畫像石選集 (A Catalogue of Pictorial Stones from Shandong). Jinan: Qi Lu shushe.

Shi, Aimin 施愛民. 1997. “Gansu Gaotai Luotuocheng huaxiang zhuanmu diaocha 甘肅高臺駱駝城畫像磚墓調查 (A Study of the Pictorial Tombs of Luotuo City, Gaotai, Gansu).” Wenwu 文物 12: 44-51.

Stein, Marc Aurel. 1928. Innermost Asia: Detailed Report of Explorations in Central Asia, Kansu and Eastern Iran. Oxford: Clarendon Press.

Sun, Wenqing 孫文清. 1932. “Nanyang Caodian Han mu huaxiangshi 南陽曹店 漢墓畫像石 (Han Pictorial Stones in Caodian, Nanyang).” Guowen zhoubao 國聞週報, Oct. 6 .

Tseng, Lillian Lan-ying. 2011. Picturing Heaven in Early China. Boston: Harvard University Press.

Uyeno, Aki. 1963. "Some Painted Pieces of Paper Bought from Turfan by the Ōtani Expedition.” Bijutsu Kenkyu 美術研究 230: 27-37.

Vampelj Suhadolnik, Nataša. 2011. "Han Mural Tombs: Reflection of Correlative Cosmology through Mural Paintings." Asian and African Studies 15 (1): $19-48$.

Wang, Jianzhong 王建中, and Shan Xiushan 閃修山, ed. 1990. Nanyang liang Han huaxiangshi 南陽兩漢畫像石 (Han Pictorial Stones from Nanyang). Beijing: Wenwu chubanshe.

Wang, Jianzhong 王建中. 2001. Handai huaxiangshi tonglun 漢代畫像石通論 (General Discourse on Han Pictorial Stones). Beijing: Zijincheng chuban she.

Wang, Qingjian 王清建. 1995. "Lun Han hua zhong de xuanwu xingxiang 論漢 畫中的玄武形象 (Discourse on Black Warrior Image in Han Paintings).” Zhongyuan wenwu 中原文物 3: 38-39.

Wang, Yu 王煜. 2018. “Han dai Fuxi, Nüwa tuxiang yanjiu 漢代伏羲、女嗗圖 像研究 (Study on Fuxi and Nüwa Imagery of the Han Dynasty).” Kaogu 考 古 3: 104-15. 
Whitfield, Roderick, and Ursula Sims-Williams. 2004. The Silk Road: Trade, Travel, War and Faith. London: British Library.

Whitfield, Roderick. 1985. Textiles, Sculpture and Other Arts. Vol. 3. Tokyo: Kodansha International Ltd (in co-operation with the Trustees of The British Museum).

Wu, Hung. 1989. The Wu Liang Shrine: The Ideology of Early Chinese Pictorial Art. Stanford: Stanford University Press.

—. 2012. "Han Sarcophagi: Surface, Depth, Context." Anthropology and Aesthetics 61/62: 196-212.

Xia, Nai 夏鼎. 1965. “Luoyang Xi Han bihuamu zhong de xingxiang tu 洛陽 西漢壁畫墓中的星象圖 (Stellar Imagery in Western Han Mural Tombs in Luoyang).” In Zhongguo gudai tianwen wenwu lunji 中國古代天文文物論 集, 162-80. Beijing: Wenwu chubanshe.

Xin, Lixiang 信立祥. 2000. Handai huaxiangshi zonghe yanjiu 漢代畫像石綜 合研究 (A Comprehensive Study of Han Pictorial Bricks). Beijing: Wenwu chubanshe.

Xing, Yitian 邢義田. 2011. Hua wei xin sheng 畫為心聲 (Images as Voices of the Heart). Beijing: Zhonghua shuju.

Xinjiang Weiwuer zizhiqu bowuguan 新疆維吾爾自治區博物館. 1972. “Tulufan xian Asitana-Halahezhuo gu muqun qingli jianbao 吐魯番縣阿斯塔 納——哈拉和卓古墓群清理簡報 (A Briefing of the Excavation at Astana and Khara-khoja Burials in Turfan).” Wenwu 文物 1: 8-29.

Yang, Lihui, Deming An, and Jessica Anderson Turner. 2005. Handbook of Chinese Mythology. ABC-CLIO.

Yang, Lihui 楊麗慧. 1999. Nüwa qiyuan: Nüwa xinyang qiyuandi de zai tuice 女媧 起源: 女媧信仰起源地的再推測 (The Origin of Nüwa: A Re-examination of the Site when the Nüwa Belief was Shaped). Beijing: Beijing shifan daxue chubanshe.

Yang, Zhefeng 楊哲峰. 2003. “Guanyu Luoyang san zuo Han bihuamu de niandai xulie wenti 關於洛陽三座漢壁畫墓的年代序列問題 (Regarding the Chronology of Three Han Tombs from Luoyang).” Wenwu 文物 2: 59-62.

Yuan, Ke 袁珂. 1980. Shanhaijing jiaozhu 山海經校注 (Annotations of the Classics of Mountains and Oceans). Shanghai: Shanghai guji chubanshe.

Zhang, Heng 張衡. 1970. Ling xian 靈憲 (Spiritual Constitution). Taipei: Yiwen yinshuguan.

Zhao, Chengfu 趙成甫, ed. 1990. Nanyang Han dai huaxiangzhuan 南陽漢代畫 像磚 (Han Pictorial Bricks from Nanyang). Beijing: Wenwu chubanshe.

Zhao, Wucheng 趙吳成. 2005. “Hexi mushi bihua zhong 'Fuxi, Nüwa' he'niushou renshen, jishou renshen’ tuxiang qianxi 河西墓室壁畫中“伏羲、女媧”和‘牛 首人身、雞首人身'圖像淺析 (A Preliminary Study of Fuxi, Nüwa, and the 
Imagery of Bull-head and Chicken-head in Mural Tombs from Hexi)." Kaogu yu wenwu 考古與文物 4: 66-70.

Zheng, Yan 鄭岩. 2002. Wei Jin Nanbeichao bihuamu yanjiu 魏晉南北朝壁畫墓研 究 (A Study of Mural Tombs during of Wei, Jin, and the Northern and Southern Dynasties). Beijing: Wenwu chubanshe.

Zheng Yan, Marianne P. Y. Wong, and Shi Jie. 2012. "Western Han Sarcophagi and the Transformation of Chinese Funerary Art." Anthropology and Aesthetics 61/62: 65-79.

Zhongguo shehui kexueyuan kaogu yanjiusuo 中國社會科學院考古研究所, and Henan dier wenwu gongzuodui 河南第二文物工作隊. 1985. “Henan Yanshi Xingyuancun Dong Han bihuamu 河南偃師杏園村東漢壁畫墓 (Eastern Han Mural Tombs from the Villiage of Xingyuan, Yanshi, Henan).” Kaogu 考古 1: 18-22, 98-99.

Zhu, Tianshu. 2003. “The Sun God and the Wind Deity at Kizil.” In Matteo Compareti, edited by Paola Raffetta and Gianroberto Scarcia, Ērān ud Anērān, Webfestschrift Marshak Studies, 681-718. Buenos Aires: Transoxiana. 